\title{
Population Fluctuation of Certain Insects Infesting Vegetable Crops and their Predators Caught by Using Light Traps and Effect of some Weather Factors on those Insects \\ Ghanim, A. A. ${ }^{1}$; H. A. El-Serafy ${ }^{1}$; H. A. Abdelwahab ${ }^{2}$ and Heba G. El-sayed ${ }^{2}$ \\ ${ }^{1}$ Economic Entomology Department, Faculty of Agriculture, Mansoura University, Egypt \\ ${ }^{2}$ Plant Protection Research Institute, Agricultural Research Center, Dokki
}

\section{ABSTRACT}

Investigation was carried out to survey the main insects attacking the vegetable crops caught by using light traps and the population fluctuations; flight activity of four nuctuids insect species and the effect of weather factors on the population fluctuations of these species during the two years (2016 and 2017) at Mansoura district. Results obtained revealed that there were nine species belonging to Family: Noctuidae (Order Lepidoptera), one species of the Family: Gelechiidae and one species of Family:Pyralidae. One species of Family: Gryllotalpidae (Order Orthoptera) were recorded. Meanwhile, one species of Family: Pentatomidae (Order Heteroptera) and one species of Family: Scarabaeidae (Order: Coleoptera) were found. Data obtained showed that the population fluctuation of Spodoptera littoralis (Boisd.) had seven peaks were found all the year round. The results cleared that Spodoptera exigua (Hubner) was recorded five peaks in vegetable crops. These peaks were occurred in the $3^{\text {rd }}$ week of March, last week of April, $2^{\text {nd }}$ week of June, $1^{\text {st }}$ week of Aug. and $3^{\text {rd }}$ week of September, during the first year of study, In the second years, the peaks were during the $1^{\text {st }}$ week of Febr, $2^{\text {nd }}$ week of May, last week of June, $3^{\text {rd }}$ week of Aug. and $1^{\text {st }}$ week of Oct. The population fluctuation of Agrotis ipsilon (Hufn.) revealed that this insect had six peaks in vegetable crops. The obtained data cleared that population fulctuation of Heliothes armigera $\mathrm{Hbn}$ This insect had four peaks in vegetable crops. These peaks were occurred in the $2^{\text {nd }}$ week of May, $2^{\text {nd }}$ week of June, $3^{\text {rd }}$ week of July and $2^{\text {nd }}$ week of Sept. during the first year of study. In the second year, the peaks were during the $3^{\text {rd }}$ week of March, last week of June, $1^{\text {st }}$ week of Aug. and $1^{\text {st }}$ week of Sept. Results indicated that the values of correlation coefficient of the relationship between the average temperature, relative humidity and the population fluctuation of these four insect species during the two seasons of study, assuted that the average temperature and relative humidity parameters exerted varied effect with a value ranged from slight to highly significant correlation during the two seasons of the investigation.

\section{INTRODUCTION}

Insects are the most species- rich taxon with about one million species described worldwide, corresponding to more than half of all known species (Groombridge, 1992;Gullan and Cranston, 2010). Due to their high ecological diversification and short generation times, insects are useful indicators of environmental change (Thomas, 2005 and Schowater, 2011). Lepidoptera (butterflies and moths) is one of the largest insect orders with 160.000 described species, of which 95\% are moths (New, 2004 and Kristensen, et al 2007).

The most widely applied method to survey moths is to use light traps, which exploit their attraction to artificial light (Franzen and Johannesson 2007; Merckx et al., 2009 and Groenendijk and Ellis, 2011).

However, many entomologists suggested the use of light traps for recording new species and for determining the relative abundance of major insect pests throughout the year. Such information may enable them to predict the possible out- breaks of certain insect species (El- Deeb et al. 1968, Ghanim 1977, Fayle et al. 2007 and Leraut 2009). Inaddition, this information makes it easier to predict the population fluctuations of such species and facilitates and lessens the amount of the used insecticides or other integrated control methods. There are many lepidopterous insect species attacking vegetable crops through the year. Many investigators studied the population fluctuations of the important insect species ( El- Mezayyen et al., 1997; ElZanan and El- Hawary, 1999; Sharma et al., 2010 and Pehlevan and Kovanci, 2013)and Wang, et al; (2014),

Weather factors, such as temperature and rainfall, relative humidity and the moon light in the open during new moon week and full moon week was found to show a significant negative lunar periodicity of macrolepidoptera catches (Hosny, 1955).

Many entomologists announced the importance of light traps as successful method of testing the relationships of weather factors and the activity of vegetable crops insect species (Hendricks et al., 1975; Ghanim, 1977 and Mark, 2014).

Therefore, this study aimed to survey the main insect species attacking the vegetable crops and their predators at Mansoura district and the population fluctuations and flight activity of four noctuids insect species infesting vegetable crops and the effect of some weather factors on the population fluctuations of these species.

\section{MATERIALS AND METHODS}

1-Survey and population fluctuation of main insect pestes attacking vegetable crops and their predatory insects:

For studying the abundance and population fluctuation of main insect species infesting vegetable crops and their predators at Mansoura, district, samples were taken daily during two years from 26th December 2016 till 25th December 2018, by using two Robison light traps (Robinson and Robinson 1950). The traps were placed in the farm of farm of faculty of Agriculture, Mansoura University at a height of 7 meters. The two light traps were baited with mercury vapour lamps ( 250 walt) as a source of light.

The trap consists of an inverted metal cone, 24 inches in diameter, and contains six radial vanes projecting two inches above the upper aperture. These vanes obstruct the flight of insects circling or heading for the light and thus reduce their flight speed causing them to stall and fall into the sloping cone and then into the receptacle. At the lower aperture of the cone and in the center of the vanes, a 250 watt clear mercury vapour lamp is fixed in a socket and so adjusted that its light is unobstructed above the upper structure is fitted tightly on a barrel -like 24 inches deep receptacle which forms the base of the apparatus. Sodium cyanide, put in a glass jar, is used as a killing agent inside the trap. The light trap was set off daily for a period of 12 hours from sunset to sunrise.

The traps were emptied every morning and the traps catches were singly placed in polyethylene sac, then the catch was brought to the laboratory for identification. 
The daily catch was separated, identified, counted and recorded at the same day. The daily catch was a accumulated biweekly for the two years of study.

Daily records of temperature and relative humidity of Mansoura district were obtained from meterological organization, Ministry of Defence. These records have been calculated as mean of biweekly degrees related to the accumulated biweekly catch of the insect species.

2-Effects of some weather factors on the population fluctuation of four insect species attacking vegetable crops and their predators

The correlation coefficients between the mean biweekly numbers of the four insect species attacking vegetable crops and their predators and the mean biweekly temperature degrees and the relative humidity were statistically calculated.

3-Statistical analysis:

For the purpose of statistical analysis, data were analyzed by using two way analiysis of variance (ANOVA),correlation coefficaticient and multiple regression equation using computer advanced statistical program (Costat 1990).

\section{RESULTS AND DISCUSSION}

1: Effectiveness of light traps in monitoring certain insect pests infesting vegetable crops.

Surveying insect species infesting vegetable crops by using light trap at Mansoura district :

The total numbers and percentages of insect species infesting vegetable crops during the two years 2016 and 2017 at Mansoura district by using light traps. It counted every biweekly to indicate the abundance and population fluctuation of these insect pests were given in Table (1). From this table, it can be seen that, there were nine species belonging to Family: Noctuidae (Order Lepidoptera), one species of the Family: Gelechiidae and one species of Family:Pyralidae. One species of Family: Gryllotalpidae (Order Orthoptera) was recorded. One species of Family: Pentatomidae (Order Heteroptera) and one species of Family: Scarabaeidae (Order: Coleoptera) were found. The noctuid insects were: Spodoptera littoralis (Boisd.), Spodoptera exigua (Hubner), Agrotis ipsilon (Hufn.), Autographa gamma L., Autographa chalcytes L., Autographa ni L., Heliothes armigera Hbn, Phthorimaea operculella (Zeller) and Cryptoblabes gnidiella (Mill).

The Gryllotalpidae, Pentatomidae and Scarabaeidae insects were Gryllus domesticus L., Nezara viridula (Linnaneus) and Pentodon algerinum dispar Baudi. It can be stated from this Table that the most dominant species was Agrotis ipsilon which represented $22.80 \%$ of the total catch in 2016 and S. littoralis and H. armigera which represented $20.26 \%$ of the total catch in 2017 .

2 - Surveying some predators associated with these insect by using light trap at Mansoura district:

The total number and percentages of predators during 2016 and 2017 year at Mansoura district by using light traps were counted biweekly to indicated that the abundance and population fluctuation of these predatory insects are given in Table (2) From this table it can be seen that, there were two species belonging to Family: Chrysopidae order Neuroptera and Family: Anthocoridae. These species were Chrysoperla carnea and Orius albidipennis.

El- Mezyyen et al. (1997), in Egypt mentioned that twenty two insect species were recorded by using light traps and S. littoralis constituted $53.34 \%$ of the total catch.
II. Population fluctuation of four insect species infesting vegetable crops by using light traps at Mansoura district:

\section{1- Spodoptera littoralis:}

Data represented in Figure (1) showed that the population fluctuation of $S$. littoralis during the two years of study. The biweekly catch revealed that this insect had seven peaks was found all the year round. These peaks were occurred in the 3rd week of Feb., 3rd week of April, 2nd week of June and 2nd week of July., the third week of August., 1st week of October and in the 2nd week of November during the first year of study. In the second years, these peaks were recorded in the 3rd week of March, last week of June, 1st week of Augast, 1st week of Sept. and 3rd week of October at Mansoura district the results were similar as indicated by Hassanein (1956) the moths of S.littoralis were captured in all months of the year at Shebin El-kom and the maximum abundance was during June and July. Ghanim (1977) found that $S$. littoralis had seven generation at Mansoura district. These generations beginning at the second week of April, last week of May, last week of June, last week of July, last week of August first, first week of October and last week of November. Ye Shu Guang et al. (2000) in China who stated that most dominant insect species was $S$. littoralis followed by A. ipsilon then S. exigua. Nandihulli et al. (1990) in India assured that the light traps was more effective at capturing individual of $S$. littoralis and $H$. armigera. Ye Shu Guang et al, (2000) in china who stated that most domenant insect species was Spodoptera litura followed by Agrotis ipsilon then Spodoptera exigua . Wandihulli et al, (1990) in India assured that the light traps was more effective at capturing individua of s.littoralis and H.armiger.

Table 1. Total Numbers and percentages of insect species infesting vegetable crops caught by light trap at Mansoura district during 2016 and 2017.

\begin{tabular}{|c|c|c|c|c|}
\hline \multirow{2}{*}{$\begin{array}{l}\text { years } \\
\text { Orders and insects } \\
\text { species }\end{array}$} & \multicolumn{2}{|c|}{2016} & \multicolumn{2}{|l|}{2017} \\
\hline & $\begin{array}{c}\text { Total } \\
\text { individuals }\end{array}$ & $\%$ & $\begin{array}{c}\text { Total } \\
\text { individuals }\end{array}$ & $\%$ \\
\hline \multicolumn{5}{|c|}{ Order: Lepidoptera } \\
\hline \multicolumn{5}{|c|}{ 1-Fam: Noctuidae } \\
\hline Spodoptera littoralis & 2303 & 14.3 & 3368 & 20.26 \\
\hline Spodoptera exigua & 1795 & 11.1 & 2584 & 15.54 \\
\hline Agrotis ipsilon & 3667 & 22.80 & 2174 & 13.07 \\
\hline Autographa gamma & 825 & 5.11 & 667 & 4.01 \\
\hline Autographa chalcytes & 625 & 3.88 & 534 & 3.22 \\
\hline Autographa ni & 1068 & 6.64 & 770 & 4.63 \\
\hline Heliothes armigera & 1541 & 9.58 & 3368 & 20.26 \\
\hline \multicolumn{5}{|c|}{ 2-Fam.:Gelechiidae } \\
\hline Phthorimaea operculella & 1439 & 8.94 & 1148 & 6.94 \\
\hline \multicolumn{5}{|c|}{ 3-Fam.:Pyralidae } \\
\hline Cryptoblabes gnidiella & 437 & 2.00 & 232 & 1.39 \\
\hline \multicolumn{5}{|c|}{ Order:Orthoptera } \\
\hline \multicolumn{5}{|c|}{ Fam.:Gryllotalpidae } \\
\hline Gryllus domesticus & 1209 & 7.5 & 918 & 5.52 \\
\hline \multicolumn{5}{|c|}{ Order:Heteroptera } \\
\hline \multicolumn{5}{|c|}{ Fam.:Pentatomidae } \\
\hline Nezara viridula & 1151 & 7.15 & 832 & 5.00 \\
\hline \multicolumn{5}{|c|}{ Order: Coleoptera } \\
\hline \multicolumn{5}{|c|}{ Fam.:Searabaeidae } \\
\hline Pentodon dispar & 20 & 1.00 & 27 & 0.16 \\
\hline Grand total numbers & 16080 & 100 & 16622 & 100 \\
\hline
\end{tabular}

B. Effect of temperature and relative humidity on the population fluctuation of Spodoptera littoralis. The values of correlation coefficient which describe the relation between temperature and the relative humidity parameters cleared highly significant positive or negative correlation during 2016 
and 2017 years The combined effect of temperature and relative humidity exerted highly positive significant correlation in the two years of investigation. The obtain results assured that the temperature parameters was the main weather factors which affected greatly on the population size of Spodoptera littoralis which cought by light traps. During the two years 2016 and 2017 the values of proportional effect (explained variance) of temperature and the relative humidity parameters tested were ranged from $83 \%$ to $14 \%$ (Table 3 )

Table 2. Total numbers of some predatory insects and their percentages to the total catch related to their orders caught by using light traps inhabiting vegetable crops.

\begin{tabular}{lcccc}
\hline Years & \multicolumn{2}{c}{$\mathbf{2 0 1 6}$} & \multicolumn{3}{c}{$\mathbf{2 0 1 7}$} \\
\hline Predatory species & Total numbers & \% & Total numbers & \% \\
\hline $\begin{array}{l}\text { Neuroptera: } \\
\text { Family: chrysopidae }\end{array}$ & 336 & 37.92 & 96 & 16.61 \\
$\begin{array}{l}\text { Chrysoperla carnea } \\
\text { Heteroptera: }\end{array}$ & & & & \\
$\begin{array}{l}\text { Family: Anthocoridae } \\
\text { Orius albidipennis }\end{array}$ & 550 & 62.08 & 482 & 83.39 \\
\hline Total numbers & 886 & 100 & 578 & 100 \\
\hline
\end{tabular}

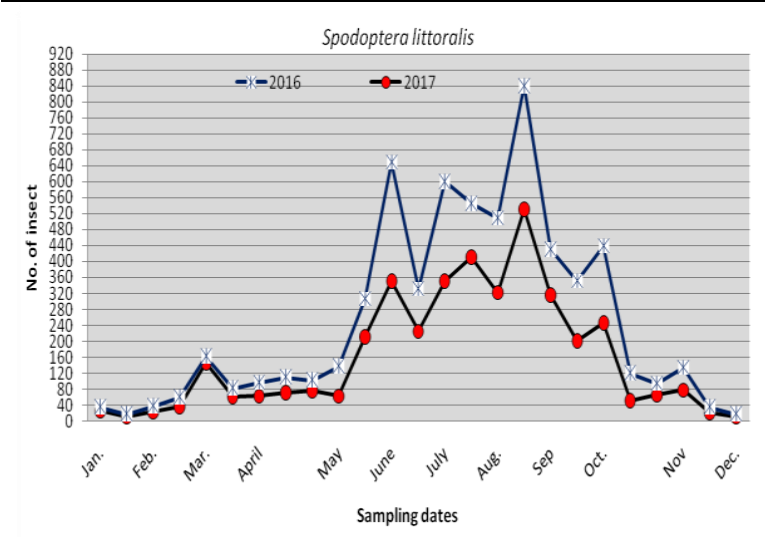

Figure 1. Population fluctuation of Spodoptera littoralis caught by using light trap during 2016 and 2017 at Mansoura district.

Table. 3. Correlation coefficient and regression between the population density of $S$. littoralis, the temperature and relative humidity components during 2016 and 2017 at Mansoura district.

\begin{tabular}{lcccc}
\hline \multirow{2}{*}{ year } & \multicolumn{2}{c}{ Simple correlation coefficient (r) } & \multicolumn{2}{c}{ Regression (R2) } \\
\cline { 2 - 5 } & $\begin{array}{c}\text { Average } \\
\text { Temperature }\end{array}$ & $\begin{array}{c}\text { Average } \\
\text { R.H. }\end{array}$ & $\begin{array}{c}\text { Average } \\
\text { Temperature }\end{array}$ & $\begin{array}{c}\text { Average } \\
\text { R.H. }\end{array}$ \\
\hline \multirow{2}{*}{2016} & $0.67 \pm$ & $0.238 \pm$ & $0.83 \pm$ & $0.14 \pm$ \\
& $0.15 * * *$ & $0.19 \mathrm{~ns}$ & 2.158 & 1.176 \\
\hline \multirow{2}{*}{2017} & $0.703 \pm$ & $-0.133 \pm$ & $0.17 \pm$ & $-0.2122 \pm$ \\
& $0.142 * * *$ & $0.198 \mathrm{~ns}$ & 3.542 & 3.151 \\
\hline \multirow{2}{*}{ ns= non significant } & $*$ & $=$ significant with varied degree & where $\mathbf{r}=$
\end{tabular}
correlation coefficient $p=$ probability $s=$ significant sign.

Results obtained in Table (3) indicated that the values of correlation coefficient of the relationship between the average temperature, relative humidity and the population density of $S$. littoralis during the two years of study. The average temperature and relative humidity parameters exerted varied effect with a value ranged from non-significant to highly significant correlation during the two years of the investigation.

\section{2-Spodoptera exigua:}

Data illustreated in Figure (2) revealed that the population density of S. exigua during the two years of study. The biweekly catch revealed that this insect had five peaks in vegetable crops. These peaks were occurred in the 3rd week of March, last week of April, 2nd week of June, 1st week of
Aug. and 3rd week of Sep. during the first year of study. In the second years, the peaks were during the 1st week of Febr, 2nd week of May, last week of June, 3rd week of Aug. and 1st week of Oct. at Mansoura district.

B. Effect of temperature and relative humidity on the population fluctuation of Spodoptera exigua. The values of correlation coefficient which describe the relation between temperature and the relative humidity parameters cleared highly significant positive or negative correlation during 2016 and 2017 years The combined effect of temperature and relative humidity exerted highly positive significant correlation in the two years of investigation. The obtain results assured that the temperature parameters was the main weather factors which affected greatly on the population size of Spodoptera exigua which cought by light traps. During the two years 2016 and 2017 the values of proportional effect (explained variance) of temperature and the relative humidity parameters tested were ranged from $84 \%$ to $11 \%$ (Table 4 )

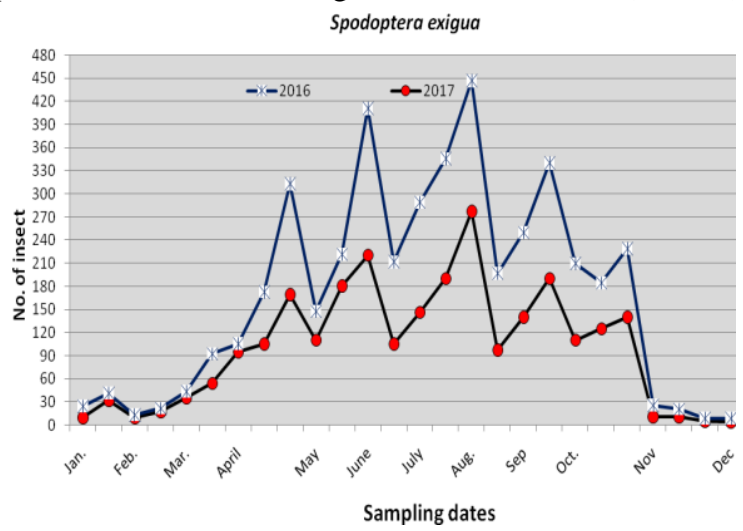

Figure 2. Population fluctuation of Spodoptera exigua caught by using light traps during 2016 and 2017 at Mansoura district.

Table 4. Simple correlation coefficient and regression between the population fulcuation of S. exigua, the temperature and relative humidity components during 2016 and 2017 at Mansoura district.

\begin{tabular}{ccccc}
\hline \multirow{2}{*}{ years } & \multicolumn{2}{l}{ Simple correlation coefficient (r) } & \multicolumn{2}{c}{ Regression (R2) } \\
\cline { 2 - 5 } & $\begin{array}{c}\text { average } \\
\text { Temperature }\end{array}$ & $\begin{array}{c}\text { average } \\
\text { R.H. }\end{array}$ & $\begin{array}{c}\text { average } \\
\text { Temperature }\end{array}$ & $\begin{array}{c}\text { Average } \\
\text { R.H. }\end{array}$ \\
\hline \multirow{2}{*}{2016} & $0.742 \pm$ & $0.276 \pm$ & $0.72 \pm$ & $0.11 \pm$ \\
& $0.134 * * *$ & $0.192 \mathrm{~ns}$ & 1.314 & 0.785 \\
\hline \multirow{2}{*}{2017} & $0.815 \pm$ & $0.077 \pm$ & $0.84 \pm$ & $0.52 \pm$ \\
& $0.115^{* * *}$ & $0.199 \mathrm{~ns}$ & 1.204 & 1.352 \\
\hline
\end{tabular}

ns $=$ in significant $*$ = significant with varied degree where

$\mathbf{r}=$ correlation coefficient $\mathbf{p}=$ probability $\mathbf{s}=$ significant sign.

Results obtained in Table (4) indicated that the values of correlation coefficient of the relationship between the average temperature, relative humidity and the population density of $S$. exigua during the two years of study. The average temperature and relative humidity parameters exerted varied effect with a value ranged from non significant to highly significant correlation during the two years of the investigation. Wang Kaiyuan et al. (1995) in China recorded 4-5 generations annually on vegetables crops by using light traps. Ming et al. (2006) mentioned that three light traps were evaluated for monitoring beet armyworm (S. exigua and $S$. littoralis). It possessed higher reliability and efficiency and lower cost and therefore is practical to be applied for forecasting and controlling of S. exigua and S. littoralis.

3-Agrotis ipsilon:

Data represented in Figure (3) cleared that the population fluctuation of $A$. ipsilon during the two years of 
study. The biweekly catch showed that this insect had six peaks in vegetable crops. These peaks were occurred in the $1^{\text {st }}$ week of March, $3^{\text {rd }}$ week of April, last week of May, $1^{\text {st }}$ week of Aug, $3^{\text {rd }}$ week of Oct and $2^{\text {nd }}$ week of Nov. during the first year of study. In the second year, the peaks were during the $3^{\text {rd }}$ week of April, last week of May, $3^{\text {rd }}$ week of Aug. and $2^{\text {nd }}$ week of Nov. at Mansoura district. B. Effect of temperature and relative humidity on the population fluctuation of $A$. ipsilon. The values of correlation coefficient which describe the relation between temperature and the relative humidity parameters cleared highly significant positive or negative correlation during 2016 and 2017 years The combined effect of temperature and relative humidity exerted highly positive significant correlation in the two years of investigation. The obtain results assured that the temperature parameters was the main weather factors which affected greatly on the population size of A.ipsilon which cought by light traps. During the two years 2016 and 2017 the values of proportional effect (explained variance) of temperature and the relative humidity parameters tested were ranged from $84 \%$ to $13 \%$ (Table 5)

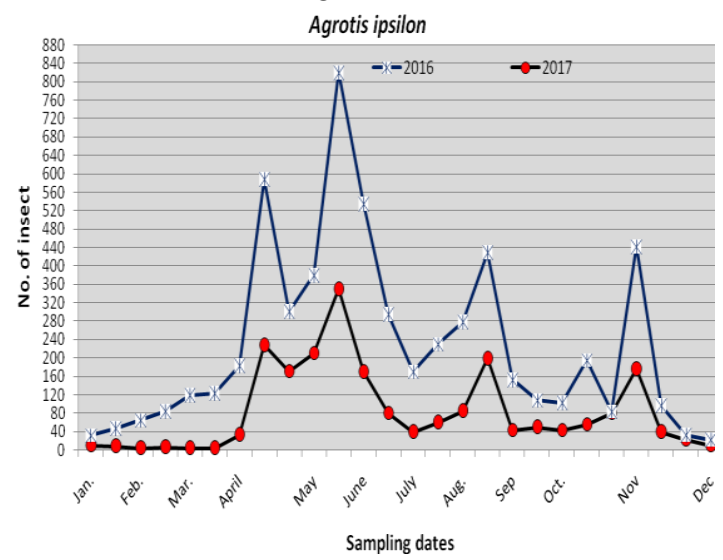

Figure 3. Population fluctuation of $\boldsymbol{A}$. ipsilon caught by using light trap during 2016 and 2017 at Mansoura district.

Results obtained in Table (5) indicated that the values of correlation coefficient of the relationship between the average temperature, relative humidity and the population density of $A$. ipsilon during the two years of study. The average temperature and relative humidity parameters exerted varied effect with a value ranged from slight to negative significant correlation during the two years of the investigation. Meshram et al. (1990) in India stated that there were ten insect species attacking vegetables crops were recorded, the dominant species of them, A. ipsilon and $H$. armeigra.

Table 5. Simple correlation coefficient and regression between the population fulcutaion of A.ipsilon, the temperature and relative humidity components during 2016 and 2017 at Mansoura district.

\begin{tabular}{ccccc}
\hline \multirow{2}{*}{ years } & \multicolumn{2}{c}{ Simple correlation coefficient (r) } & \multicolumn{2}{c}{ Regression (R2) } \\
\cline { 2 - 5 } & $\begin{array}{c}\text { average } \\
\text { Temperature }\end{array}$ & $\begin{array}{c}\text { average } \\
\text { R.H. }\end{array}$ & $\begin{array}{c}\text { average } \\
\text { Temperature }\end{array}$ & $\begin{array}{c}\text { average } \\
\text { R.H. }\end{array}$ \\
\hline \multirow{2}{*}{2016} & $0.444 \pm$ & $0.177 \pm$ & $0.83 \pm$ & $0.13 \pm$ \\
& $0.179^{*}$ & $0.196 \mathrm{~ns}$ & 3.350 & 1.533 \\
2017 & $0.425 \pm$ & $-0.308 \pm$ & $0.84 \pm$ & $0.39 \pm$ \\
& $0.181^{*}$ & $0.190 \mathrm{~ns}$ & 3.589 & 2.407 \\
\hline
\end{tabular}

ns = in significant $*$ = significant with varied degree where $\mathbf{r}=$ correlation coefficient

$\mathbf{p}=$ probability $\mathbf{s}=$ significant sign

Jakubowska and Bocianowski (2013) observed a local, growing population of cutworm in agricultural fields with various plants such as vegetables, horticultural, and ornamental plants has been observed. The scope of study covered the observation of two species of cutworms: Agrotis segetum (Schiff.). The overall results can be used for adjusting the currently used monitoring methods for shortterm and long-term forecasting of cutworm flights, and for optimizing chemical control of the cutworm.

\section{4-Heliothis armigera:}

Data illustrated in Figure (4) recorded the population fluctuation of $H$. armigera during the two years of study. The biweekly catch revealed that this insect had four peaks in vegetable crops. These peaks were occurred in the $2^{\text {nd }}$ week of May, $2^{\text {nd }}$ week of June, $3^{\text {rd }}$ week of July and $2^{\text {nd }}$ week of Sept. during the first year of study. In the second year, the peaks were during the $3^{\text {rd }}$ week of March, last week of June, $1^{\text {st }}$ week of Aug. and $1^{\text {st }}$ week of Sept. at Mansoura district. B. Effect of temperature and relative humidity on the population fluctuation of H.armigera. The values of correlation coefficient which describe the relation between temperature and the relative humidity parameters cleared highly significant positive or negative correlation during 2016 and 2017 years The combined effect of temperature and relative humidity exerted highly positive significant correlation in the two years of investigation. The obtain results assured that the temperature parameters was the main weather factors which affected greatly on the population size of H.armigera which cought by light traps. During the two years 2016 and 2017 the values of proportional effect (explained variance) of temperature and the relative humidity parameters tested were ranged from $82 \%$ to $10 \%$ (Table 6)

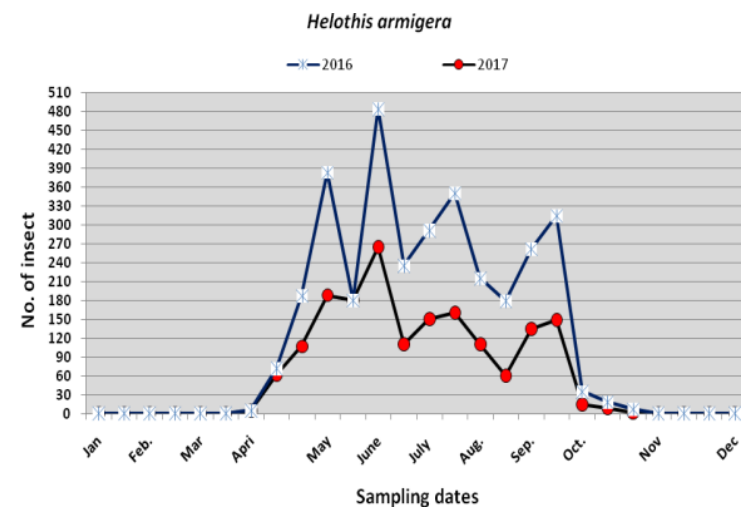

Figure 4. Population fluctuation of Heliothis armigera caught by using light traps during 2016 and 2017 at Mansoura district.

Table 6. Simple correlation coefficient and regression between the population density of $H$. armigera, the temperature and relative humidity components during 2016 and 2017 at Mansoura district.

\begin{tabular}{ccccc}
\hline \multirow{2}{*}{ years } & \multicolumn{2}{c}{ Simple correlation coefficient $(\mathbf{r})$} & \multicolumn{2}{c}{ Regression (R2) } \\
\cline { 2 - 5 } & $\begin{array}{c}\text { Average } \\
\text { Temperature }\end{array}$ & $\begin{array}{c}\text { Average } \\
\text { R.H. }\end{array}$ & $\begin{array}{c}\text { average } \\
\text { Temperature }\end{array}$ & $\begin{array}{c}\text { average } \\
\text { R.H. }\end{array}$ \\
\hline \multirow{2}{*}{2016} & $-0.04367 \pm$ & $0.0052 \pm$ & $-0.1000 \pm$ & $0.10 \pm$ \\
& $0.199 \mathrm{~ns}$ & $0.0049 \mathrm{~ns}$ & 0.457 & 0.190 \\
\hline \multirow{2}{*}{2017} & $0.648 \pm$ & $-0.136 \pm$ & $0.82 \pm$ & $-0.11 \pm$ \\
& $0.152^{* * *}$ & $0.198 \mathrm{~ns}$ & 1.934 & 1.606 \\
\hline
\end{tabular}

ns $=$ non significant $*$ = significant with varied degree where $\mathbf{r}=$ correlation coefficient

$\mathbf{p}=$ probability $\mathrm{s}=$ significant sign .

Results obtained in Table (6) indicated that the values of correlation coefficient of the relationship between the average temperature, relative humidity and the population 
density of $H$. armigera during the two years of study. The average temperature and relative humidity parameters exerted varied effect with a value ranged from non significant to highly significant correlation during the two years of the investigation. Deepa et al. (2009) in India recorded mentoring and relationship between light raps catches of $H$. armigera showed that traps catches and positively correlated with temperature and negatively correlated with relative humidity.

\section{REFERENCES}

Ang, Y.S. ;Cheng , X.F.; Liao, C.Z. (2000). Control of insect pests in vegetable fields with the frequence vibration type trap lamp. Plant Prot.; 26(5):45-46.

Cai, w.y. ; Guo,W.E. ;Fu,W.H. (2014) Study on population dynamics of beet armyworm in the suburbs of Linhai city, Zhejiang Province, China. Acta Agriculturae Zhejiangensis; 26 (3):760-763.

CoHort softwer (2004). Costat www.cohort.com Monterey, California, USA.

Deepa, M.; A. Neerja; V. Rahul; K. Kiran; K. M. Lal (2009). Monitoring and weather parameters on Bactrocera complex through methyl eugenol traps. Ann. Plant Prot. Sci. 17(2):332-336. 10 ref.

El-Deeb, A. A., Hammad, S. M. and Amer, A. I. (1968) Studies on the spiny Bollworm Earias insulana Boisd in Alexandria area. Alex. J. Agric. Res. Vol. 16:7-12.

El-Mezayyen, G. A.; A. A. EL-Dinah.; G.M Moawad and M.S. Tadoros (1997) . A modified light trap as a tool for insects survey in relation to the main weather factors. EGYPT. J . Agric . Res. 75: 4, 995-1006.

EL-Zanan, A. A. and I. S. EL-Hawary (1999). Infestation with cotton leafworm and bollworms in relation to pheromone and light trap catches in cotton fields. Egypt. J . Agric . Res , 77: 2, 647-661.

Fayle ,TM, Sharp R.E., Majerus , M.E.N. (2007). The effect of moth trap type on catch size and composition in British Lepidoptera. Brit J Entomol Nat Hist 20: 221.

Franzen , M . and Johannesson M. (2007) . Predicting extinction risk of butterflies and moth (Macrolepidoptera) from distribution patters and species characteristics. J Insect Conserv 11:367-390.

Ghanim , A. A. (1977) Ecological studies on certain cotton pests in Dakahlia Province. M.SC. Thesis. fac. Agric. Alex. Univ. pp. 123.

Groenendijk D.and Ellis WN (2011) The state of the Dutch larger moth fauna. J Insect Conserv 15:95-101.

Groombridge, B. (1992). Global biodiversity : status of the earth's living resources. London: Chapman \& Hall. $585 \mathrm{p}$.

Gullan, P.J and Cranston P.S. (2010). The Insect: An Outline of Entomology. Chichester: John Wiley \& Sons. 590p.
Hendricks, D. E, Lingren , P. D. and Hollingasworth, J. P. (1975) Numbers of bollworms, tabaco budworms, and cotton leaf-worms caught in traps equipped with fluorescent lamps of five colours. J. Econ. Ent. Vol. 68.

Hosny, M. M. (1955) Notes on the effect of some secondary environmental conditions on the activity of nocturnal Macrolepidoptera. Bull. Soc. Ent. Egypt. Vol. 39: 297.

Kristensen, N. P; Scoble, M.J,and Karsholt O.(2007). Lepidoptera phylogeny and systematic: the state of inventorying moth and butterfly diversity. Zootaxa 1668: 699-747.

Leraut P. (2009) Moths of Europe: Geometrid moths. France: Napeditions. 795 p.

Meshram, P.B.; S.C. Pathak and Jamaluddin (1990) population dynamics and seasonal abundance of some forest insect pests ( nursery stage) through light trap. India. Foreste, 116:6, 494-503.

Merckx T.; Feber, RE; Riordan, P; Townsend, M.C. ,and Bourn N.A. (2009). Optimizing the biodiversity gain from agri-environment schemes. Agric. Ecosyst Eviron 130: 177-182.

Ming L. H.; Guo YuRen; and Wu XiangWen (2006). Evaluation of different sex pheromone lures and light traps for trapping and monitoring the adults of Spodoptera exigua and S. litura. China Vegetables, (4):17-19.

Nandihalli, B.S.; B.V. patil.; S. Somasekar and P. Hugar (1990). A comparative assessment of pheromone and light-trap catches of cotton pests. J. India. Society . Cotton . Improvement. 15: 2, 148-150.

New, T.R. (2004). Moths ( Insecta: Lepidoptera) and conservation: background and perspective. J Insect Conserv 8: 79-94

Pehlevan, B. and Kovanci, O.B. (2013). Monitoring adult populations of Tuta absoluta in field-grown processing tomatoes in northwestern Turkey. Proc. $4^{\text {th }}$ Intern. Scientific- Expert Conf. Agric.\& Food Industry, Sarajevo Univ. 396-400.

Sharma, A. K.; , S. Barche and K. P. Mishra, (2010). Pest and predatory insect species inhabiting paddy ecosystem in Jabalpur, Madhya Pradesh collected with the help of light traps. Pest Manag \&Econo.zool. 18(1/2):125-133.

Schowalter TD (2011) Insect Ecology: An Ecosystem Approach. London: Academic Press. 633 p.

Thomas J. A. (2005) Monitoring change in the abundance and distribution of insects using butterflies and other indicator group. Philos T R Soc B - Biol Sci 360: 339- 357.

Uan, W.K.; Gxu, Q.G.; Jiu, G.Q. (1995). Development and control of Laphygma exigua in onion fields. Bulletin of Agricultural Science and Technology; (11):27.

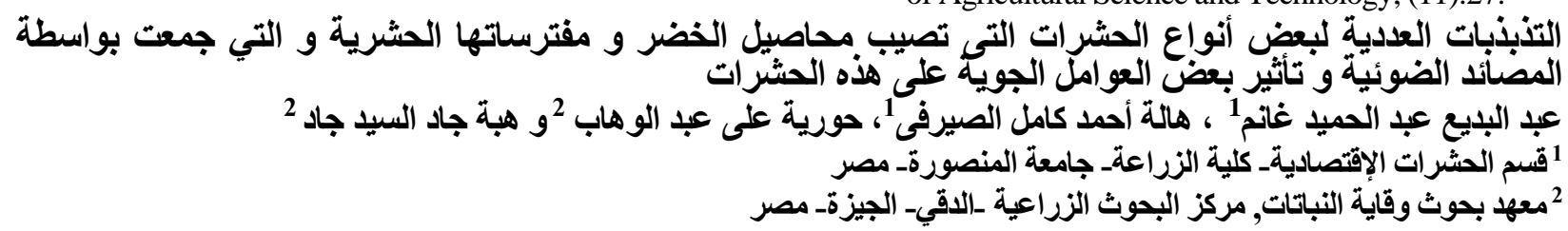

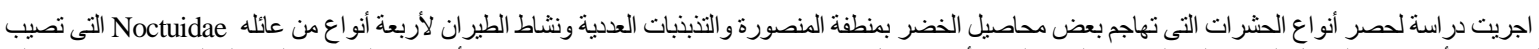
مائلّ مائل

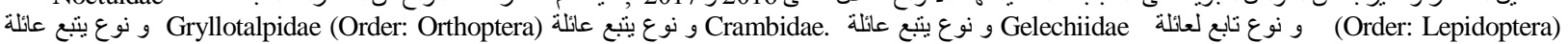

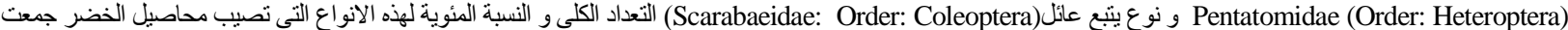

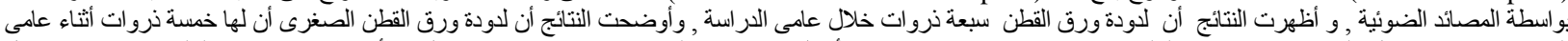

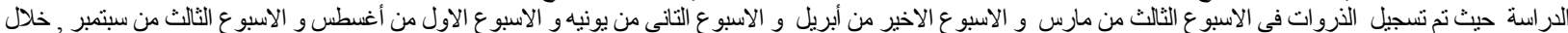

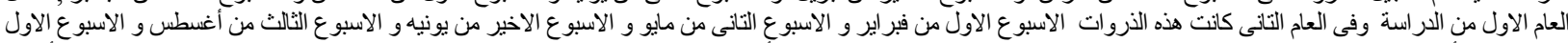

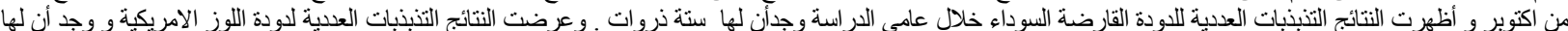

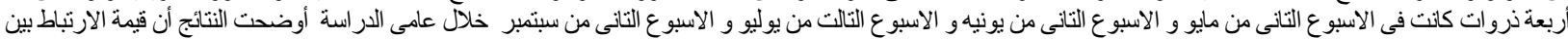

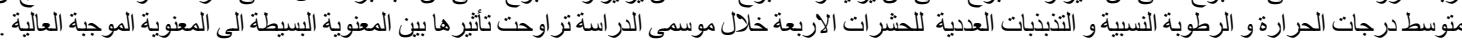

